\title{
Gastric cancer and concomitant renal cancer: A systematic immunohistochemical and molecular analysis
}

\author{
JOHANNES BETGE ${ }^{1}$, MARION J. POLLHEIMER ${ }^{1}$, ANDREA SCHLEMMER ${ }^{2}$, \\ GERALD HOEFLER $^{1}$ and CORD LANGNER ${ }^{1}$ \\ ${ }^{1}$ Institute of Pathology, and ${ }^{2}$ Institute for Medical Informatics, Statistics and \\ Documentation, Medical University of Graz, 8036 Graz, Austria
}

Received March 12, 2011; Accepted April 28, 2011

DOI: $10.3892 /$ or.2011.1346

\begin{abstract}
The frequency of gastric cancer in patients with renal cell carcinoma (RCC) is exceptionally high in our region suggesting a common molecular basis. Our study aimed to characterize tumors and to analyze possible underlying molecular features in 12 patients with gastric cancer and concomitant RCC. We performed an immunohistochemical analysis including p53 protein expression, proliferative activity (MIB-1), mismatch repair status (hMLH1, hMSH2, hMSH6, PMS2) and E-cadherin expression in gastric cancers, which were additionally analyzed for Epstein-Barr-Encoded-RNA (EBER) by in situ hybridization. Microsatellite instability was analyzed with a PCR multiplex system and capillary electrophoresis. KRAS mutations in codons 12 and 13 were tested by pyrosequencing. All patients had clear cell RCCs, 10 of which were well differentiated and diagnosed in an early stage, while the gastric cancers of these patients were generally poorly or undifferentiated and diagnosed in an advanced stage. Gastric cancers showed reduced E-cadherin staining in 10 out of 12 cases. Two gastric cancers demonstrated loss of hMLH1 and PMS2, which was confirmed by molecular analysis showing a high degree of microsatellite instability. All RCCs were microsatellite stable. KRAS mutation was detected in one of the two instable gastric cancers, while none of the RCCs had KRAS mutations. Another gastric cancer was positive for EBV. In conclusion, a coherent cause for gastric cancer and concomitant RCC, such as Lynch syndrome, a prominent role of KRAS mutation or EBV infection, was not found in our series. Other factors leading to a higher susceptibility for cancer must be explored to explain why individuals with RCC have a higher risk of developing gastric cancer in our region.
\end{abstract}

Correspondence to: Dr Cord Langner, Institute of Pathology, Medical University of Graz, Auenbruggerplatz 25, 8036 Graz, Austria E-mail: cord.langner@medunigraz.at

Key words: multiple primary neoplasms, hereditary neoplasms, in situ hybridization, microsatellite instability, KRAS, Epstein-Barr virus

\section{Introduction}

Patients with multiple malignancies constitute an attractive research topic. The analysis of different tumors occurring in a single patient may lead to the detection of hereditary causes for cancer or cancer syndromes and may improve understanding of general molecular pathologic principles of carcinogenesis.

Gastric cancer is the fourth most common cancer worldwide (1). Familial clustering is observed in approximately $10 \%$ of cases, but only 1-3\% of these are hereditary (2). Cases with familial clustering are classified into familial diffuse gastric cancer (FDGC), including hereditary diffuse gastric cancer (HDGC), a cancer syndrome caused by a germline mutation in the E-cadherin (CDH1) gene $(2,3)$, as well as familial intestinal gastric cancer (FIGC) or, if the histology is unknown, familial gastric cancer (FGC) (4). Moreover, gastric cancer may be observed as part of a hereditary tumor syndrome with the main localization other than the stomach. Thus, germline mutations of the BRCA1 and BRCA2 genes do not only increase the risk for breast and ovarian cancer, but do also increase the incidence of stomach, pancreas, prostate and colorectal cancer (5). Li-Fraumeni syndrome is caused by mutations of the tumor-suppressor gene TP53. Affected patients suffer from a wide spectrum of tumors, including breast and colorectal cancer, soft tissue or bone sarcoma, brain tumors, and, though infrequently, also gastric cancer (6). Finally, gastric cancer represents a well known extracolonic manifestation of the Lynch (HNPCC) syndrome (7). Neoplasms occurring as part of the Lynch syndrome are characterized by microsatellite instability (MSI) caused by germline mutations in mismatch repair genes (8).

None of the syndromes mentioned above have been reported to increase the risk for renal cell carcinoma (RCC). Nevertheless, the association of primary gastric and primary renal cancer has been presented in several case reports (9-22). Likewise, in the RCC database of our institute, we found 12 patients, who, in addition to RCC, also experienced gastric cancer, either synchronously or metachronously. The observed incidence was nearly twice as high as documented in the National Cancer Registry regarding the gastric cancer incidence in Austria (23).

Therefore, the present study aimed to evaluate patients with gastric and concomitant renal cancer. This is the first 
Table I. Antibodies used for immunohistochemical staining.

\begin{tabular}{llllll}
\hline Antibody & \multicolumn{1}{c}{ Source } & Clone & Dilution/Epitope retrieval & Detection system & Chromogen \\
\hline p53 & Dako & DO-7 & $1: 100 /$ WB, Buffer pH 6.0 & B & AEC \\
MIB-1 & Ventana & K-2 & Ready to use/Ventana iView Kit & A & DAB \\
E-cadherin & Zymed, San Francisco, CA, USA & 4 A2C7 & Ready to use/MW, Buffer pH 9.0 & C & AEC \\
hMLH1 & Biocare, Concorde, CA, USA & G168-15 & $1: 50 /$ MW, Buffer pH 9.0 & C & DAB \\
hMSH2 & Ventana & G219-1129 & $1: 50 /$ Buffer CC1 standard & D & DAB \\
hMSH6 & Biocare & BC-44 & $1: 50 /$ Buffer CC1 mild & D & DAB \\
PMS2 & BD Biosciences, San Jose, Ca, USA & A 16-4 & $1: 50 /$ MW, Buffer pH 6.0 & C \\
\hline
\end{tabular}

A, Ventana iView DAB; B, Dako REAL Detection System K5001; C, Dako EnVision+ (HRP rab/mouse) K5007; D, Ventana ultraView DAB 760-500. DAB, diaminobenzidine Dako (K5001); AEC, aminoethylcarbazole Dako (S2367); Buffer pH 9.0, Target Retrieval Solution Dako (S2367); Buffer pH 6.0, Epitope Retrieval Solution Dako (K5207). WB, water bath; MW, microwave; CC1, Ventana (950-124 SL).

study to systematically assess this association. First of all, we characterized the clinical and pathological presentation of these patients, analyzed epidemiologic and clinical data and presented histopathological and immunohistochemical features. In a second step, in order to analyze possible underlying genetic as well as infectious factors in the pathogenesis of both cancer types, we performed a thorough molecular analysis with respect to MSI, KRAS mutation and EpsteinBarr-Encoded-RNA (EBER) status.

\section{Materials and methods}

Patient selection. A systematic search of the RCC database of the Institute of Pathology, Medical University of Graz, Austria, covering 2082 patients (1180 males, 902 females; ratio 1.3:1) who underwent radical or partial nephrectomy between January 1984 and September 2005 was performed to identify those with synchronous and/or metachronous diagnosis of cancer in gastric biopsies or resection specimens. The medical records of these patients were reviewed in order to differentiate between patients with primary gastric cancer and those with secondary gastric involvement by RCC.

Patients with RCC metastatic to the stomach were presented in a previous publication (24), in which we described the clinical significance of this rare finding. During analysis, another 12 patients with synchronous and/or metachronous occurrence of both primary gastric and primary RCC were identified who represent the scope of the current analysis.

Clinicopathological and follow-up data of the 12 patients were analyzed in detail by chart review and interviewing attending physicians if possible. Basic personal data, such as patient age and gender were compared with data of patients suffering from either gastric or renal cancer contained in the computerized RCC and/or gastric cancer databases of our institution, respectively. The gastric cancer database covers 3072 patients (1689 males, 1378 females; ratio 1.2:1) who underwent total or partial gastrectomy between January 1984 and December 2008.

This study was carried out in accordance with the Declaration of Helsinki (2000) of the World Medical Association. Institutional Review Board approval was obtained from the Ethics Committee of the Medial University of Graz, Austria.
Histopathology. All tumor probes were carefully reassessed, paying special attention to tumor stage and grade as well as histological subtype of both renal and gastric cancers. Tumors were staged according to the 7th edition of the American Joint Committee on Cancer - Union Internationale Contre le Cancer (AJCC-UICC) Tumor-Node-Metastasis (TNM) Classification (25). Tumor grades were assessed following the WHO guidelines on renal (26) and gastric (27) cancers, respectively. Gastric cancers were additionally classified according to the Laurén classification (28).

Immunohistochemistry. Tissues were routinely fixed in $4 \%$ buffered formalin and embedded in paraffin. Sections $(4-\mu \mathrm{m})$ were stained using automated staining systems (Dako TechMate $^{\mathrm{TM}}$ 500; Dako, Glostrup, Denmark/Benchmark XT; Ventana Medical Systems, Tucson, AZ, USA) and commercially available antibodies (Table I). Epitope retrieval was performed and standardized for each antibody, using either microwave treatment, protease digestion or prediluted commercially available epitope retrieval solutions. Binding of the primary antibodies was visualized using the HRP/DAB+ Dako REAL ${ }^{\mathrm{TM}}$ detection system (catalog no. K5001, Dako) or the ultraView ${ }^{\mathrm{TM}}$ Universal DAB detection kit (catalog no. 760-500, Ventana), respectively.

Immunoreactivity was independently assessed by two investigators (M.J.P. and C.L.), and discrepancies were resolved by simultaneous re-examination of the slides by both investigators using a double-headed microscope. Regarding p53 and MIB-1, positivity was identified as brown nuclear staining. The number of positive cells (labeling index) was determined by counting positive cells per 100 cancer cells, and immunoreactivity was semi-quantitatively assessed as follows: negative $(<10 \%)$, weak or $1+(11-20 \%)$, moderate or $2+(21-50 \%)$ and high or $3+(>50 \%)$. The amount of E-cadherin staining was evaluated in relation to staining of non-neoplastic mucosa and was assessed as reduced, when up to $50 \%$ of cancer cells lost specific membranous labeling, markedly reduced, when $>50 \%$ lost specific membranous labeling, negative or positive. Regarding the four MMR proteins (hMLH1, hMSH2, hMSH6, PMS2), staining was recorded as either present (positive) or absent (negative).

Slides of a colorectal cancer known to exhibit high p53 as well as E-cadherin expression served as positive controls for 
Table II. Patient and tumor characteristics.

\begin{tabular}{|c|c|c|c|c|c|c|c|c|c|c|c|c|}
\hline \multirow[b]{2}{*}{$\begin{array}{l}\text { Patient } \\
\text { no. }\end{array}$} & \multicolumn{6}{|c|}{ Renal cell carcinoma (RCC) } & \multicolumn{5}{|c|}{ Gastric cancer } & \multirow[b]{2}{*}{ Outcome } \\
\hline & Gender & $\begin{array}{c}\text { Age } \\
\text { (years) }\end{array}$ & $\mathrm{pT} / \mathrm{pN}$ & Grade & $\begin{array}{l}\text { Histological } \\
\text { subtype }\end{array}$ & $\begin{array}{l}\text { Size } \\
(\mathrm{cm})\end{array}$ & $\begin{array}{l}\text { Age } \\
\text { (years) }\end{array}$ & $\mathrm{pT} / \mathrm{pN}$ & Grade & $\begin{array}{l}\text { Histology/Lauren } \\
\text { classification }\end{array}$ & $\begin{array}{l}\text { Location/ } \\
\text { size }(\mathrm{cm})\end{array}$ & \\
\hline 1 & M & 64 & $1 \mathrm{~B} / \mathrm{X}$ & 2 & Clear cell & 5.5 & 70 & $\mathrm{X} / \mathrm{X}$ & 3 & $\begin{array}{l}\text { Signet ring cell } \\
\text { with mucinous } \\
\text { component/diffuse }\end{array}$ & Cardia/X & $\begin{array}{l}\text { AWD (peritoneal metastases) } \\
2 \text { months after diagnosis of gastric } \\
\text { cancer (no tumor resection) }\end{array}$ \\
\hline 2 & M & 57 & $1 \mathrm{~A} / \mathrm{X}$ & 2 & Clear cell & 2 & 63 & $3 / 1$ & 4 & $\begin{array}{l}\text { Undifferentiated/ } \\
\text { diffuse }\end{array}$ & $\begin{array}{l}\text { Antrum/ } \\
5.5\end{array}$ & $\begin{array}{l}\text { DOD } 10 \text { months after diagnosis of } \\
\text { gastric cancer }\end{array}$ \\
\hline 3 & $\mathrm{~F}$ & 78 & $1 \mathrm{~A} / \mathrm{X}$ & 2 & Clear cell & 3 & 78 & $3 / 1$ & 3 & $\begin{array}{l}\text { Signet ring } \\
\text { cell/diffuse }\end{array}$ & $\begin{array}{c}\text { Corpus/ } \\
2.2\end{array}$ & $\begin{array}{l}\text { Synchronous CRC (T3 N0) and renal } \\
\text { oncocytoma, DOD } 3 \text { years after } \\
\text { tumor diagnosis }\end{array}$ \\
\hline 4 & M & 68 & $1 \mathrm{~A} / \mathrm{X}$ & 1 & Clear cell & 1.2 & 61 & $2 / 1$ & 3 & $\begin{array}{l}\text { Signet ring cell } \\
\text { with mucinous } \\
\text { component/diffuse }\end{array}$ & Corpus/3 & $\begin{array}{l}2 \text { metachronous CRC, AWD (hepatic, } \\
\text { pulmonal and bone metastases) } \\
10 \text { years after diagnosis } \\
\text { of gastric cancer }\end{array}$ \\
\hline 5 & $\mathrm{~F}$ & 66 & $1 \mathrm{~A} / \mathrm{X}$ & 1 & Clear cell & 3 & 67 & $2 / 2$ & 2 & $\begin{array}{l}\text { Tubular with mucinous } \\
\text { component/intestinal }\end{array}$ & Cardia/6 & $\begin{array}{l}\mathrm{BC} 4 \text { years prior to } \mathrm{RCC}, \mathrm{AWD} \\
\text { (bone metastases) } 8 \text { years after } \\
\text { diagnosis of } \mathrm{BC}\end{array}$ \\
\hline 6 & M & 75 & $3 \mathrm{~A} / \mathrm{X}$ & 2 & Clear cell & 7 & 75 & $3 / 2$ & 3 & Tubular/intestinal & Antrum/6 & $\begin{array}{l}\text { AWD (local recurrence of gastric } \\
\text { cancer) } 8 \text { months after tumor diagnosis }\end{array}$ \\
\hline 7 & M & 69 & $1 \mathrm{~A} / \mathrm{X}$ & 2 & Clear cell & 3.5 & 68 & $3 / 0$ & 4 & $\begin{array}{l}\text { Tubular with } \\
\text { undifferentiated } \\
\text { component/mixed }\end{array}$ & $\begin{array}{c}\text { Gastric } \\
\text { stump/ } \\
4.5\end{array}$ & $\begin{array}{l}\text { NED } 10 \text { years after diagnosis of } \\
\text { gastric cancer }\end{array}$ \\
\hline 8 & M & 45 & $1 \mathrm{~A} / \mathrm{X}$ & 2 & Clear cell & 4 & 55 & $\mathrm{X} / \mathrm{X}$ & 4 & $\begin{array}{l}\text { Undifferentiated/ } \\
\text { diffuse }\end{array}$ & $\begin{array}{c}\text { Fundus/ } \\
\mathrm{X}\end{array}$ & $\begin{array}{l}\text { Hepatic metastases at time of } \\
\text { diagnosis of gastric cancer, } \\
\text { no follow-up }\end{array}$ \\
\hline 9 & M & 75 & $1 \mathrm{~A} / \mathrm{X}$ & 2 & Clear cell & 3.2 & 75 & $3 / 2$ & 3 & $\begin{array}{l}\text { Signet ring cell/ } \\
\text { diffuse }\end{array}$ & Corpus/6 & $\begin{array}{l}\text { DOC (myocardial infarction) } 1 \text { year } \\
\text { after tumor diagnosis }\end{array}$ \\
\hline 10 & M & 41 & $1 \mathrm{~A} / \mathrm{X}$ & 1 & Clear cell & 4 & 41 & $3 / 3$ & 3 & $\begin{array}{l}\text { Signet ring cell } \\
\text { with mucinous } \\
\text { component/diffuse }\end{array}$ & Corpus/9 & $\begin{array}{l}\text { DOD } 2 \text { years after tumor diagnosis } \\
\text { of gastric cancer }\end{array}$ \\
\hline 11 & $\mathrm{~F}$ & 55 & $1 \mathrm{~A} / \mathrm{X}$ & 1 & Clear cell & 3.5 & 62 & $3 / 3$ & 3 & $\begin{array}{l}\text { Adenosquamous/ } \\
\text { mixed }\end{array}$ & $\begin{array}{l}\text { Antrum/ } \\
7.6\end{array}$ & $\begin{array}{l}\text { AWD (hepatic, peritoneal and bone } \\
\text { metastases) } 4 \text { years after diagnosis } \\
\text { of gastric cancer }\end{array}$ \\
\hline 12 & $\mathrm{~F}$ & 78 & $3 \mathrm{~A} / \mathrm{X}$ & 3 & Clear cell & 4.5 & 78 & $1 \mathrm{a} / \mathrm{X}$ & 1 & Papillary/intestinal & $\begin{array}{l}\text { Antrum/ } \\
\mathrm{X}\end{array}$ & $\begin{array}{l}\text { AWD (pulmonal, bone, hepatic and } \\
\text { pancreas metastases) } 1 \text { year after } \\
\text { tumor diagnosis }\end{array}$ \\
\hline
\end{tabular}

Age, age at diagnosis. NED, no evidence of disease; AWD, alive with disease; DOD, died of disease; DOC, died of other causes; CRC, colorectal cancer; BC, breast cancer.

p53, E-cadherin and MIB-1 immunostaining, respectively. Intratumoral lymphocytes served as positive controls for MMR proteins. Negative controls included omission of the primary antibodies and incubation with Dako REAL antibody diluent (no. S2022, Dako).

In situ hybridization. In situ hybridization was performed on paraffin-embedded sections (4- $\mu \mathrm{m})$ using the INFORM EBER assay (Ventana) according to the manufacturer's instructions (regarding positive and negative controls and RNA preservation controls within samples) and an automated slide stainer system (Benchmark XT, Ventana). Briefly, after deparaffin- ization and rehydration, tissues were treated with proteinase $\mathrm{K}$ and then hybridized with the fluorescein-labeled EBER oligonucleotide probe (INFORM EBER Probe, Ventana). The hybridized probe was visualized using an in situ hybridization detection system (ISH iVIEW Blue detection kit, Ventana), which utilizes an anti-fluorescein primary antibody binding to the EBER probe and a biotinylated secondary antibody formulation binding to the primary mouse antibody. Streptavidin-conjugated alkaline phosphatase was then used as a chromogenic enzyme, which generates a blue nuclear signal, which is evaluated by light microscopy. A nasopharyngeal carcinoma was used as a positive control. 
Molecular analysis. DNA from formalin-fixed paraffinembedded tissue was extracted using the Qiagen QIAmp DNA Mini Kit (Qiagen, Hilden, Germany) according to the manufacturer's recommendations, in an elution volume of $50 \mu 1$.

MSI was investigated using the Promega Microsatellite Analysis System version 1.2 (Promega, Mannheim, Germany), a PCR multiplex system using 5 mononucleotide markers (BAT-25, BAT-26, NR-21, NR-24, MONO-27) to determine MSI and 2 pentanucleotide repeat markers (Penta $\mathrm{C}$ and Penta D) for internal control. Two separate analyses using 50 and $100 \mathrm{ng}$ of DNA, respectively, were performed. PCR products were separated by capillary electrophoresis using an ABI Prism 3100 genetic analyzer (Applied Biosystems, Vienna, Austria). According to the instructions, MSI at 2 mononucleotide loci was reported as MSI-high, instability at one locus as MSI-low and no instability at any of the loci tested as microsatellite stable (MSS).

We tested for KRAS mutations in codons 12 and 13 by pyrosequencing using the Pyromark Q24 KRAS kit v2.0 (Qiagen). Two analyses, using 20 and $40 \mathrm{ng}$ of DNA, respectively, were performed. The amplification was carried out in a $25-\mu 1$ reaction volume, containing $5 \mu \mathrm{l}$ of DNA solution, $0.5 \mu$ l of codon $12+13$ biotinylated reverse primers, $0.5 \mu \mathrm{l}$ forward primer, $2.5 \mu \mathrm{l}$ Qiagen buffer, $0.2 \mu \mathrm{l}$ of each $\mathrm{dNTP}$, and $0.16 \mu \mathrm{l}$ Qiagen Taq polymerase. The amplification profile was $15 \mathrm{~min}$ at $95^{\circ} \mathrm{C} ; 45$ cycles with $20 \mathrm{sec}$ at $95^{\circ} \mathrm{C}$, $30 \mathrm{sec}$ at $53^{\circ} \mathrm{C}$ and $20 \mathrm{sec}$ at $72^{\circ} \mathrm{C}$; followed by $5 \mathrm{~min}$ at $72^{\circ} \mathrm{C}$. PCR products $(8 \mu \mathrm{l})$ were analyzed by electrophoresis in a $3 \%$ agarose gel to confirm successful amplification. To prepare single-stranded DNA, the PCR products were immobilized with streptavidin sepharose beads and purified with the PyroMark Q24 Vacuum Workstation. Pyrosequencing primer $(25 \mu \mathrm{l})$ was annealed to the purified single-stranded PCR product. After pyrosequencing using the nucleotide dispensation order TACGACTCAGATCGTAG results were analyzed with PyroMark Q24 software.

\section{Results}

Clinical data/outcome analysis. The incidence of gastric cancer in RCC patients included in the RCC database of our institution was $27 / 100,000$, compared with the gastric cancer incidence of 14/100,000 recorded in the Austrian cancer registry for the same study period (23).

Of the 12 patients, 8 were male and 4 were female. Gastric cancer was diagnosed at a mean age of 66 years (median 65, range 41-78), compared with 68 years (median 69, range 11-97) in the gastric cancer database. Accordingly, RCC was diagnosed at a mean age of 64 years (median 67, 41-78), compared with 62 years (median 63, range 9-88) in the RCC database. In 5 patients, RCC was diagnosed prior to gastric cancer; in 5 patients, synchronous to gastric cancer, and in 2 patients RCC was diagnosed after gastric cancer, respectively.

Detailed information regarding the patients, such as outcome analysis and presence of tertiary malignancies, is presented in Table II.

Histology. Details concerning the histology of all tumors including $\mathrm{T}$ and $\mathrm{N}$ classification, tumor size and location, as well as Laurén's classification for gastric cancer are presented in Table II. Briefly, all RCCs were of clear cell type. In general, they were well differentiated and were predominantly diagnosed at an early tumor stage. None of the RCCs had lymph node metastases.

Gastric tumors were poorly differentiated in the vast majority of cases and were generally diagnosed at a higher tumor stage. Five tumors were diagnosed as signet ring cell carcinomas (patients nos. 1, 3, 4,9 and 10) of which three showed extracellular mucin production (nos. 1, 4 and 10; Fig. 1A). One patient (no. 5) had a moderately differentiated tubular adenocarcinoma with a mucinous component, one patient (no. 11) an adenosquamous (Fig. 1B) and another patient (no. 12) a well-differentiated papillary carcinoma. Three tumors were diagnosed as undifferentiated carcinomas (nos. 2, 7 and 8 ) of which one showed areas of a pre-existing moderately differentiated tubular adenocarcinoma (no. 7). The undifferentiated carcinoma of patient no. 2 showed large areas of necrosis and was found to be densely infiltrated by mixed inflammatory cells (Fig. 1C). The undifferentiated carcinoma with pre-existing better differentiated areas of patient no. 7 was characterized by a dense intratumoral and peritumoral lymphoplasmacellular infiltrate including lymph follicle formation (Fig. 1D).

The colorectal cancer of patient no. 3 was a poorly differentiated adenosquamous carcinoma with a mucinous component $(<50 \%$ of the tumor area), while both colorectal cancers of patient no. 4 were poorly differentiated adenocarcinomas with a mucinous component ( $<50 \%$ of the tumor area).

Immunohistochemistry. Regarding gastric tumors, high (3+) proliferative activity (MIB-1) was present in the majority of cases (Fig. 2A). P53 protein overexpression was observed in 7 carcinomas and varying loss and/or reduction of membranous E-cadherin immunolabeling in 10 carcinomas (Fig. 2B and C). Two gastric cancers (patients nos. 2 and 11) showed loss of nuclear expression of mismatch repair proteins hMLH1 and PMS2 (Fig. 2D and E). This finding was confirmed by molecular analysis showing a high degree of MSI (Table III, compare below). All RCCs as well as the three colorectal cancers from patients nos. 3 and 4 retained mismatch repair protein expression.

In situ hybridization. Presence of EBV was demonstrated in the gastric cancer characterized by dense intratumoral lymphoplasmacellular infiltrate in H\&E-stained sections (patient no. 7), whereas all other tumors were negative (Fig. 2F).

Molecular analysis. Testing for MSI, we found additional peaks for the microsatellite markers NR-21, BAT-26, BAT-25, NR-24 and MONO-27 in the gastric cancer of patient no. 2, compared with the patient's normal and RCC tissue (Fig. 3). In patient no. 11 we observed a characteristic peak broadening regarding the markers NR-21, BAT-26, BAT-25 and MONO-27 in gastric cancer tissue, compared with the patient's normal and RCC tissue. Hence, we classified both patients MSI-high according to the Bethesda guidelines, which is concordant with the immunohistochemical findings in these patients. We did not find MSI in any of the RCCs. The colorectal cancers of patients no. 3 and 4 were also MSS. 

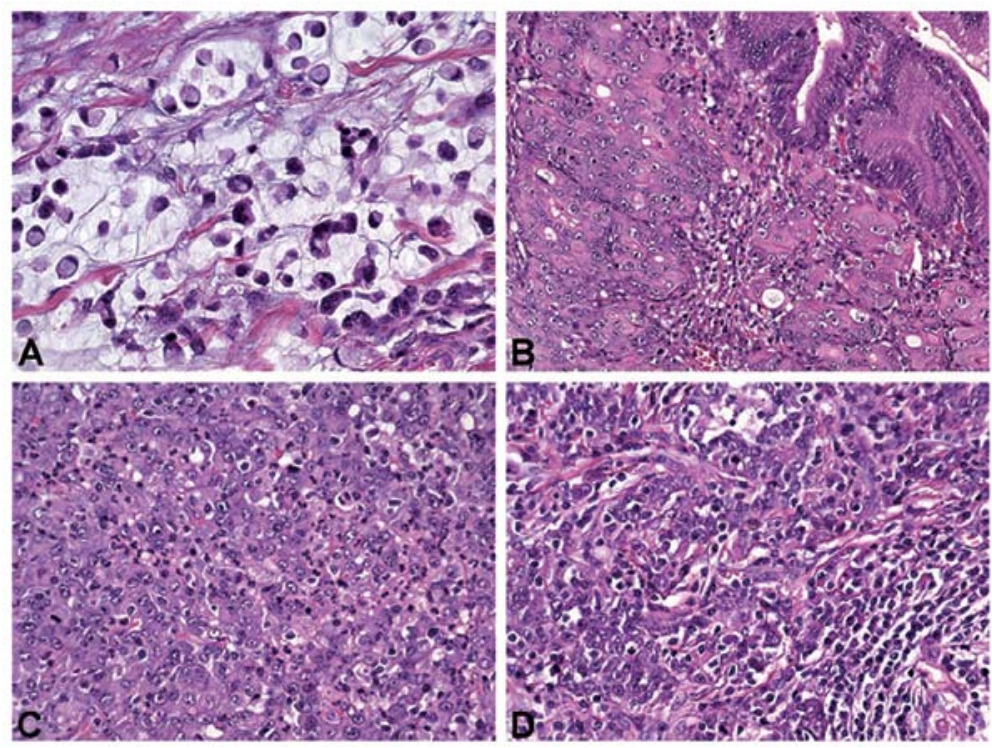

Figure 1. Morphologic diversity of gastric cancer associated with renal cell carcinoma. (A) Signet ring cell carcinoma with extracellular mucin production (x100), (B) poorly differentiated adenosquamous carcinoma (x100) and (C) undifferentiated carcinoma with marked intratumoral inflammation with mixed infiltrate (x100) or (C) predominantly lymphoplasmacellular infiltrate (x100).

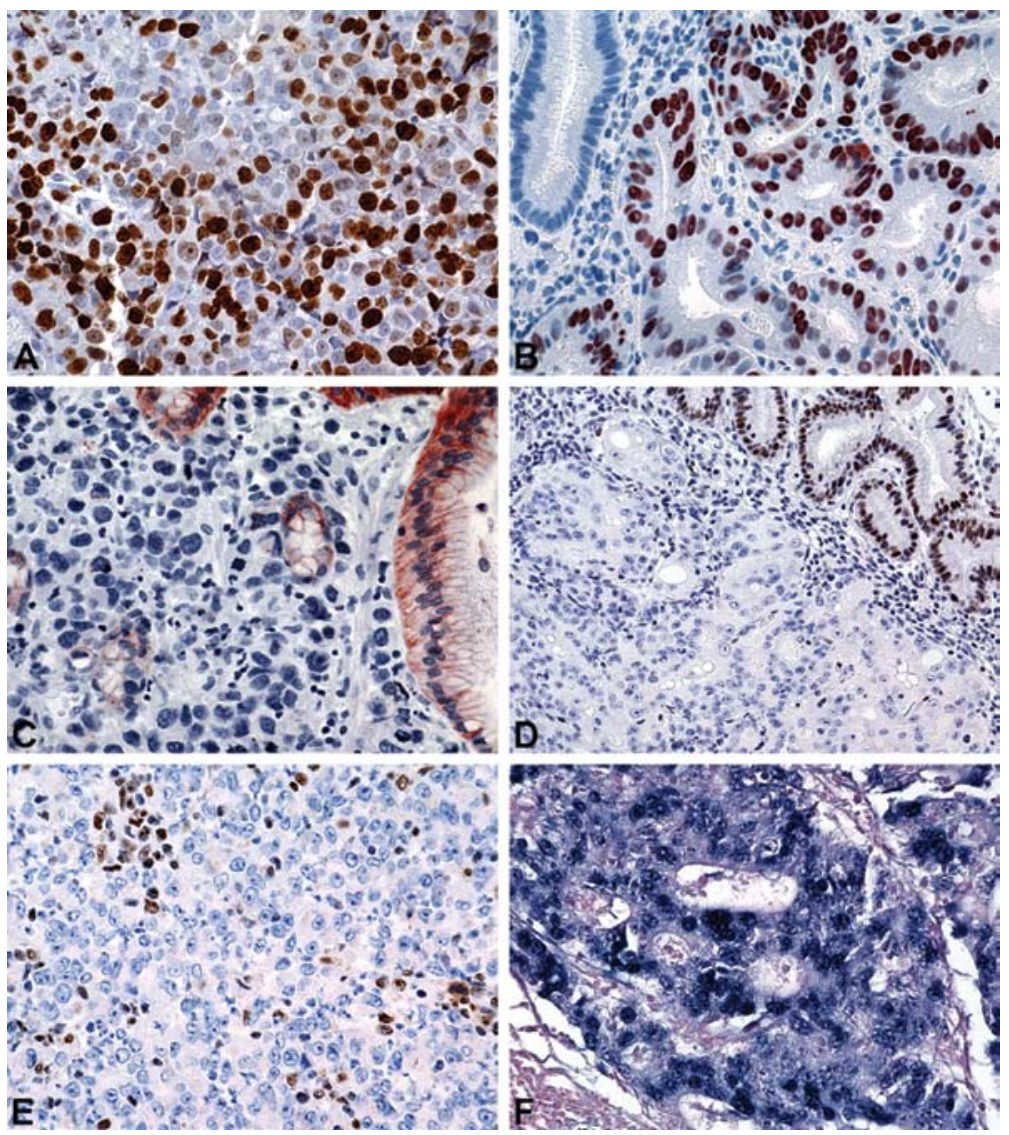

Figure 2. Immunohistochemistry and in situ hybridization of gastric cancer associated with renal cell carcinoma. (A) High proliferative activity of MIB-1 (x100) and (B) p53 overexpression of cancer cells (x100). (C) Loss of E-cadherin staining in poorly differentiated gastric cancer (x100). (D) Loss of hMLH1 (x100) and (E) PMS2 immunostaining in undifferentiated tumor tissue (x100). (F) EBER (x100).

Screening for KRAS mutations in codons 12 and 13 was positive in one of the gastric cancers; we found a transversion form guanine to cytosine at the second base of codon 12 resulting in Gly12Ala in the gastric cancer of patient no. 2 .
Additionally, we found KRAS mutations at the second base of codon 12 in both of the colorectal cancers; patient no. 3 had a transversion to thymine (Gly12Val) and patient no. 4 a transition to adenine (Gly12Asp). We did not detect KRAS mutations 
Table III. Immunohistochemical and molecular findings in gastric cancers.

\begin{tabular}{|c|c|c|c|c|c|c|c|c|c|c|}
\hline \multirow[b]{2}{*}{ Patient no. } & \multicolumn{7}{|c|}{ Immunohistochemistry } & \multicolumn{3}{|c|}{ Molecular analysis ISH } \\
\hline & p53 & MIB1 & E-cad & MLH1 & MSH2 & MSH6 & PMS2 & MSI & $K R A S$ & EBER \\
\hline 1 & +++ & +++ & $\downarrow \downarrow \downarrow$ & pos & pos & pos & pos & MSS & wt & neg \\
\hline 2 & - & +++ & pos & neg & pos & pos & neg & MSI-H & mut & neg \\
\hline 3 & - & + & $\downarrow \downarrow \downarrow$ & pos & pos & pos & pos & MSS & wt & neg \\
\hline 4 & - & +++ & $\downarrow \downarrow$ & pos & pos & pos & pos & MSS & wt & neg \\
\hline 5 & ++ & + & $\downarrow$ & pos & pos & pos & pos & MSS & wt & neg \\
\hline 6 & - & ++ & $\downarrow$ & pos & pos & pos & pos & MSS & wt & neg \\
\hline 7 & +++ & +++ & $\downarrow$ & pos & pos & pos & pos & MSS & wt & pos \\
\hline 8 & +++ & +++ & $\downarrow \downarrow \downarrow$ & pos & pos & pos & pos & MSS & $\mathrm{u}$ & neg \\
\hline 9 & +++ & + & $\downarrow \downarrow \downarrow$ & pos & pos & pos & pos & MSS & wt & neg \\
\hline 10 & +++ & +++ & $\downarrow \downarrow \downarrow$ & pos & pos & pos & pos & MSS & wt & neg \\
\hline 11 & - & + & $\downarrow$ & neg & pos & pos & neg & MSI-H & wt & neg \\
\hline 12 & +++ & +++ & pos & pos & pos & pos & pos & MSS & wt & neg \\
\hline
\end{tabular}

ISH, in situ hybridisation; E-cad, E-cadherin; pos, positive; neg, negative (or $\downarrow \downarrow$ for E-cadherin); +, weak; ++, moderate; +++, extensive; MSS, microsatellite stable; MSI-H, microsatellite instability-high; wt, wild-type; mut, mutated; u, unknown.
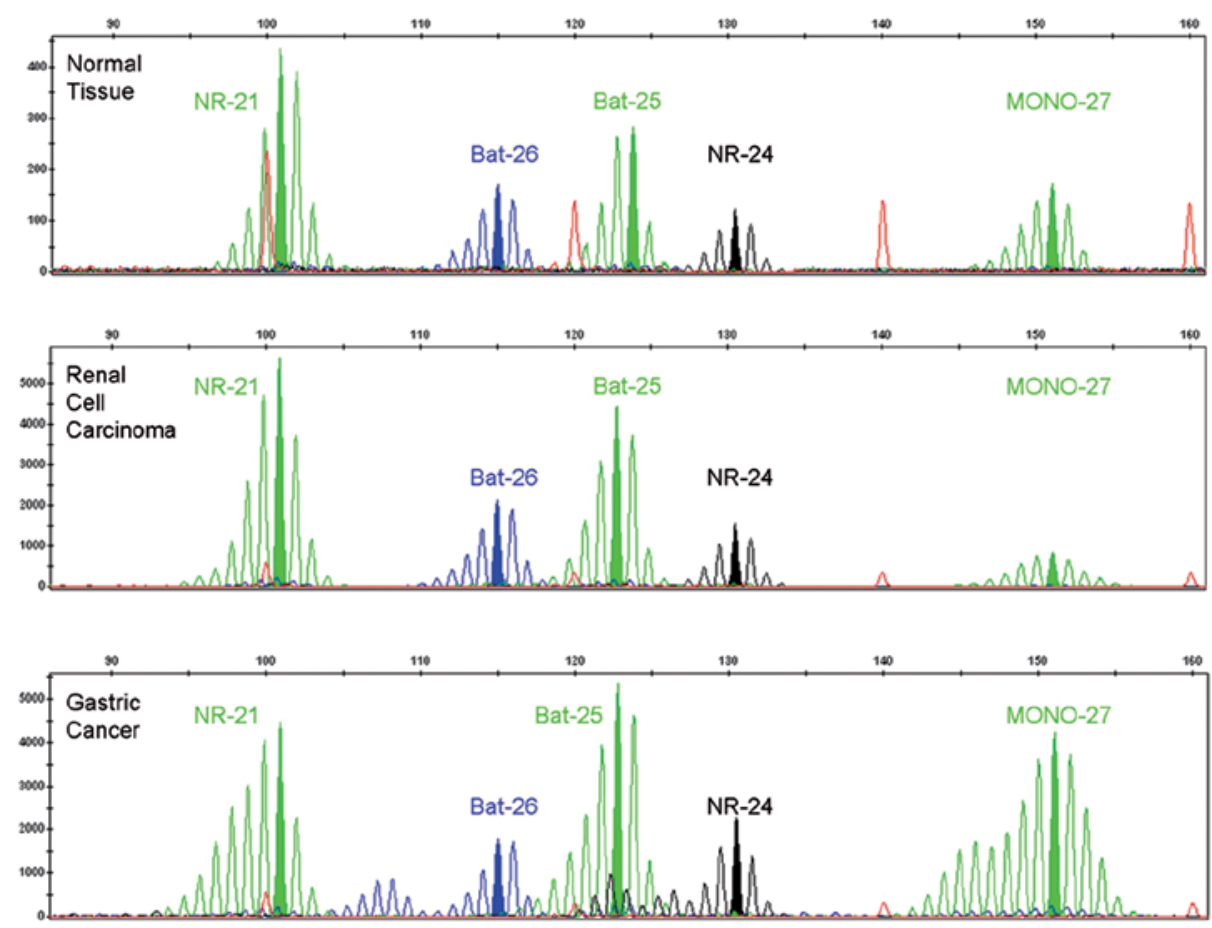

Figure 3. MSI testing shows additional peaks for the microsatellite markers NR-21, BAT-26, BAT-25, NR-24 and MONO-27 in the gastric cancer of patient no. 2, compared to the patient's normal and renal cancer tissue.

in any of the RCCs. The material of one gastric cancer could not be analyzed due to poor DNA quality. One RCC could not be subjected to molecular analysis due to insufficient material.

\section{Discussion}

Carcinogenesis is driven by progressive accumulation of somatic mutations in a number of tumor-related genes. Patients with multiple neoplasms are more likely to harbor a germline mutation in one of those genes. It is estimated that approximately 5\% of all cancers arise within a hereditary cancer syndrome, each of which present with a spectrum of tumors (29).

A systematic study analyzing the association of gastric and renal cancer is lacking. In the present study, we focused on 12 patients with gastric and synchronous and/or metachronous RCC based on the observation of a markedly high incidence of gastric cancer in patients with RCC, suggesting 
the possibility of a hitherto unrecognized genetic association or hereditary cancer syndrome.

The manifestation age regarding both gastric and renal cancer, however, was not significantly different from that of patients included in the gastric and renal cancer databases, respectively. Moreover, the male predominance of our cohort is in the line with epidemiologic data from our country, where the risk for male patients to develop gastric or renal cancer is almost twice as high as for females (23).

All RCCs were of clear cell type, which is known to represent the most common form of renal cancer worldwide. Nevertheless, it was noteworthy that 11 of the 12 tumors were well differentiated (grade 1 or 2), while the majority of gastric cancers were very poorly differentiated (grade 3 ) or even undifferentiated (grade 4) at the time of diagnosis, apart from patient no. 12, who had a well-differentiated gastric cancer and a grade 3 RCC.

Some of the poorly differentiated gastric tumors harbored marked intratumoral inflammation or presented with rather uncommon histological subtypes, such as adenosquamous carcinoma. According to literature data, intratumoral mixed or predominantly lymphoplasmacellular infiltration has been related to MSI or EBV infection (30-33), respectively. This led to the hypothesis, that Lynch syndrome may have caused gastric cancer associated with renal cancer in our cohort. In addition, we searched for EBV in cancer tissues, particularly since EBV is associated with hypermethylation of tumorsuppressor genes known to be involved gastric cancer (34).

To note, gastric cancer is the second most common extracolonic malignancy in patients with Lynch syndrome. Because of the relatively high incidence of gastric cancer in the general population, the true association of gastric cancer and Lynch syndrome is, however, controversial (35). Nevertheless, approximately $15-20 \%$ of gastric cancers are MSI. In these cases, hypermethylation of the hMLH1 promotor region appears to be the responsible mechanism $(2,36)$.

We found the gastric cancer with marked mixed infiltrate to be MSI (patient no. 2) and the gastric cancer with predominantly lymphoplasmacellular infiltrate to be associated with EBV infection (patient no. 7). The second gastric cancer with MSI showed adenosquamous differentiation (patient no. 11) which has been related to MSI-high status in $12 \%$ ( 2 out of 17) of cases (37). However, the overall incidence of MSI-high status ( 2 out of $12 ; 17 \%$ ) in our cohort of gastric cancers is in line with literature data ranging from 10 to $20 \%$ of tumors (38-42). All RCCs analyzed in our study were MSS. Data on the presence of MSI or mismatch repair gene defects in RCCs are conflicting. Reported incidences range from 0 to $40 \%$ (43-51). The fact that, in our series, both renal tumors from patients with MSI-high gastric cancers were MSS argues against germline mutations in DNA repair genes (Lynch syndrome) and we conclude that neither Lynch syndrome nor EBV infection represents a major cause with respect to carcinogenesis in our patient cohort.

A crucial pathway involved in cell proliferation is the $R A S-R A F-M E K-E R K-M A P$ kinase pathway which is frequently activated in cancer. In contrast to colorectal cancer, $B R A F$ mutations are exceedingly rare in gastric cancers and do not characterize MSI tumors (52). The frequency of $K R A S$ mutations in gastric cancer ranges between 0 and $8.5 \%$
(36,37,53-57). In RCCs the incidence of $K R A S$ mutations is lower (58), while activating mutations in the KRAS gene are found in 30-40\% of colorectal carcinomas (59). Patient no. 2 had a gastric cancer harboring a KRAS mutation and was also MSI. Additionally, we observed KRAS mutations in both of the analyzed colorectal carcinomas, but in none of the RCCs. Hence, the observed frequencies in our patients are in agreement with the literature. In addition, data suggest that KRAS mutations are more frequent in MSI-high gastric cancers than in MSS. Thus, Brennetot et al (60) observed KRAS mutations in $28 \%$ of MSI gastric cancer, while no mutations were noted in MSS tumors.

Finally, there are some hereditary cancer syndromes that may cause clear cell RCC, but none of these is related to a higher frequency of gastric cancer. Most common is von Hippel-Lindau disease, which leads to (often multifocal) clear cell RCC and renal cysts and is additionally associated with $\mathrm{CNS}$ and retinal haemangioblastomas, pheochromocytomas, pancreatic cysts and neuroendocrine tumors as well as endolymphatic sac tumors of the inner ear, epididymal and broad ligament cystadenomas (61). The Birt-Hogg-Dubé syndrome also includes clear cell RCC or oncocytoma, but most often chromophobe or oncocytic hybrid tumors as renal manifestation, while fibrofolliculomas, trichodiscomas and acrochordons may be noted as extra-renal manifestations. Moreover, spontaneous pneumothoraces due to lung cysts are frequent in these patients (61). Finally, clear cell RCC may also occur in patients with constitutional chromosome 3 translocation, a very rare syndrome leading to multiple bilateral clear cell RCCs without additional systemic manifestations (62). All these syndromes, however, do not fit with the clinicopathological presentation of our patients.

In conclusion, we found that in our region, patients with RCC have a markedly higher risk to develop gastric cancer than the rest of the population. The 12 analyzed patients had a comparable clinicopathological presentation, consisting of well-differentiated clear cell RCCs and poorly differentiated, aggressive gastric cancers. The presented cases could not be assigned to a known hereditary cancer syndrome, such as Lynch syndrome. In addition, KRAS mutations did not play a major role in our cases nor did EBV infection. Other genetic changes leading to a higher susceptibility for cancer may explain why some people have a higher risk to develop (multiple) malignancies. This will have to be explored in future studies.

\section{Acknowledgements}

The authors are grateful to Mrs. G. Winter, Mrs. E. Grygar, and Mrs. A. Kaps for excellent technical assistance.

\section{References}

1. Boyle P and Levin B (eds): World Health Organization. World Cancer Report. IARC Press, Lyon, 2008.

2. Carneiro F, Oliveira C, Leite M and Seruca R: Molecular targets and biological modifiers in gastric cancer. Semin Diagn Pathol 25: 274-287, 2008

3. Humar B and Guilford P: Hereditary diffuse gastric cancer: a manifestation of lost cell polarity. Cancer Sci 100: 1151-1157, 2009.

4. Oliveira C, Seruca R and Carneiro F: Hereditary gastric cancer. Best Pract Res Clin Gastroenterol 23: 147-157, 2009. 
5. Friedenson B: BRCA1 and BRCA 2 pathways and the risk of cancers other than breast or ovarian. MedGenMed 7: 60, 2005.

6. Olivier M, Goldgar DE, Sodha N, Ohgaki H, Kleihues P, Hainaut P and Eeles RA: Li-Fraumeni and related syndromes: correlation between tumor type, family structure, and TP53 genotype. Cancer Res 63: 6643-6650, 2003

7. Lynch HT, Lynch PM, Lanspa SJ, Snyder CL, Lynch JF and Boland CR: Review of the Lynch syndrome: history, molecular genetics, screening, differential diagnosis, and medicolegal ramifications. Clin Genet 76: 1-18, 2009.

8. Aaltonen LA, Peltomäki P, Mecklin JP, et al: Replication errors in benign and malignant tumors from hereditary non-polyposis colorectal cancer patients. Cancer Res 54: 1645-1648, 1994.

9. Matsutani T, Sasajima K, Miyamoto M, et al: Resection of pancreatic metastasis from renal cell carcinoma and an early gastric cancer. J Nippon Med Sch 75: 41-45, 2008.

10. Roh JH, Kim HJ, Jang KT, Kim KM, Kim JJ, Kim S and Park CK: Metastatic renal cell carcinoma masquerading as a primary gastric carcinoma associated with synchronous early gastric carcinoma. Pathology 40: 83-85, 2008.

11. Valle L, Cascón A, Melchor L, et al: About the origin and development of hereditary conventional renal cell carcinoma in a four-generation $\mathrm{t}(3 ; 8)(\mathrm{p} 14.1 ; \mathrm{q} 24.23)$ family. Eur J Hum Genet 13: $570-578,2005$

12. Kobayashi S, Kabuto T, Doki Y, et al: Synchronous esophagea and renal cell carcinoma. Dis Esophagus 13: 305-310, 2000.

13. Mukai M, Makuuchi H, Mukohyama S, et al: Quintuple carcinomas with metachronous triple cancer of the esophagus, kidney, and colonic conduit following synchronous double cancer of the stomach and duodenum. Oncol Rep 8: 111-114, 2001.

14. Piccinini L, Luppi G, Zoboli A and Torricelli P: Occasional diagnosis of synchronous renal cell carcinoma during staging of other primary tumors. Tumori 82: 488-490, 1996.

15. Casetta G, Piana P, Gamba P, Gontero P, Bodo G, Lauro D and Calderini P: Appearance in 2 brothers of double primary neoplasms: right renal carcinoma and gastric adenocarcinoma. Minerva Urol Nefrol 47: 49-51, 1995.

16. Murakami S, Yashuda S, Nakamura T, Mishima Y, Iida $\mathrm{H}$ Okano $\mathrm{H}$ and Nakano M: A case of renal cell carcinoma with metastasis to the thyroid gland and concomitant early gastric cancer. Surg Today 23: 153-158, 1993

17. Nagral A, Mohandas KM, Swaroop D, et al: Double primary neoplasms of the stomach and kidney. Indian J Gastroenterol 10: 67-68, 1991.

18. Azuma T, Koide A, Asami H, et al: A case of synchronous multiple primary cancers of the stomach and kidney. Gan No Rinsho 36: 2605-2609, 1990.

19. Kamiya T, Ooshita H, Kubota M, et al: A case of triple carcinomas: stomach carcinoma surgically removed, renal tumor, and carcinoma of the remnant stomach. Gan No Rinsho 36: 2193-2199, 1990.

20. Funaki H, Suzuki N, Adachi M, et al: Double primary malignant neoplasm of renal cell carcinoma and stomach cancer: report of two cases. Hinyokika Kiyo 31: 1629-1634, 1985.

21. Yoshizumi Y, Shima S, Sugiura Y, Yonekawa H, Ogata T, Nagakura $\mathrm{K}$ and Aikawa A: A case of simultaneous surgery for primary double cancer of the stomach and kidney. Gan No Rinsho 31: 429-433, 1985

22. Tashiro K, Kondo N, Ueda M, et al: A case study with bladder metastasis of renal cell carcinoma and stomach cancer. Hinyokika Kiyo 30: 249-252, 1984.

23. Statistik Austria.Magen(C16)-Krebsinzidenz(Neuerkrankungen pro Jahr), Österreich ab 1983 [document on the internet]. Vienna: Bundesanstalt Statistik Österreich; 2009, cited 2011-02-10. Available from: URL:http://www.statistik.at/web_de/statistiken/ gesundheit/krebserkrankungen/magen/021771.html.

24. Pollheimer MJ, Hinterleitner TA, Pollheimer VS, Schlemmer A and Langner C: Renal cell carcinoma metastatic to the stomach: single-centre experience and literature review. BJU Int 102: 315-319, 2008

25. Sobin LH, Gospodarowicz MK and Wittekind C (eds): UICC International Union Against Cancer: TNM Classification of Malignant Tumors, 2009. 7th edition. John Riley and Sons Ltd. West Sussex, 2010

26. Eble JN, Sauter G, Epstein JI and Sesterhenn IA (eds): World Health Organization: Classification of Tumors. Pathology and Genetics - Tumours of the Urinary System and Male Genital Organs. IARC Press, Lyon, 2004.
27. World Health Organization: Classification of Tumors. Pathology and Genetics - Tumours of the Digestive System. IARC Press, Lyon, 2000.

28. Laurén P: The two histological main types of gastric carcinoma: diffuse and so-called intestinal-type carcinoma. An attempt at a histo-clinical classification. Acta Pathol Microbiol Scand 64: 31-49, 1965

29. Rahner N and Steinke V: Hereditary cancer syndromes. Dtsch Arztebl Int 105: 706-714, 2008.

30. Smyrk TC, Watson P, Kaul K and Lynch HT: Tumor-infiltrating lymphocytes are a marker for microsatellite instability in colorectal carcinoma. Cancer 91: 2417-2422, 2001.

31. Grogg KL, Lohse CM, Pankratz VS, Halling KC and Smyrk TC: Lymphocyte-rich gastric cancer: associations with Epstein-Barr virus, microsatellite instability, histology, and survival. Mod Pathol 16: 641-651, 2003

32. Chiaravalli AM, Feltri M, Bertolini V, et al: Intratumour T cells, their activation status and survival in gastric carcinomas characterised for microsatellite instability and Epstein-Barr virus infection. Virchows Arch 448: 344-353, 2006.

33. Lee HE, Chae SW, Lee YJ, Kim MA, Lee HS, Lee BL and Kim WH: Prognostic implications of type and density of tumour-infiltrating lymphocytes in gastric cancer. Br J Cancer 99: 1704-1711, 2008

34. Geddert H, Zur Hausen A, Gabbert HE and Sarbia M: EBVinfection in cardiac and non-cardiac gastric adenocarcinomas is associated with promoter methylation of p16, p14 and APC, but not hMLH1. Anal Cell Pathol (Amst) 33: 143-149, 2010.

35. Gylling A, Abdel-Rahman WM, Juhola M, et al: Is gastric cancer part of the tumour spectrum of hereditary non-polyposis colorectal cancer? A molecular genetic study. Gut 56: 926-933, 2007.

36. Milne AN, Carneiro F, O'Morain C and Offerhaus GJ: Nature meets nurture: molecular genetics of gastric cancer. Hum Genet 126: 615-628, 2009.

37. Woo DK, Lee WA, Kim YI and Kim WH: Microsatellite instability and alteration of E2F-4 gene in adenosquamous and squamous cell carcinomas of the stomach. Pathol Int 50: 690-695, 2000.

38. Wu M, Semba S, Oue N, Ikehara N, Yasui W and Yokozaki H: BRAF/K-ras mutation, microsatellite instability, and promoter hypermethylation of hMLH1/MGMT in human gastric carcinomas. Gastric Cancer 7: 246-253, 2004.

39. Zhao W, Chan TL, Chu KM, Chan AS, Stratton MR, Yuen ST and Leung SY: Mutations of BRAF and KRAS in gastric cancer and their association with microsatellite instability. Int J Cancer 108: 167-169, 2004.

40. Gu M, Kim D, Bae Y, Choi J, Kim S and Song S: Analysis of microsatellite instability, protein expression and methylation status of hMLH1 and hMSH2 genes in gastric carcinomas. Hepatogastroenterology 56: 899-904, 2009.

41. Li JH, Shi XZ, Liu M, Wang Y, Yu ZH, Xu GW and Lu S: Methylation of hMLH1 gene promoter in gastric carcinoma with microsatellite instability. Ai Zheng 24: 273-277, 2005.

42. Hamelin R, Chalastanis A, Colas C, et al: Clinical and molecular consequences of microsatellite instability in human cancers. Bull Cancer 95: 121-132, 2008.

43. Baiyee D and Banner B: Mismatch repair genes in renal cortical neoplasms. Hum Pathol 37: 185-189, 2006.

44. Diakoumis E, Sourvinos G, Kiaris H, Delakas D, Cranidis A and Spandidos DA: Genetic instability in renal cell carcinoma. Eur Urol 33: 227-232, 1998.

45. Kanomata N, Eble JN and Halling KC: Microsatellite instability is uncommon in young patients with renal cell carcinoma. Cancer Genet Cytogenet 101: 123-127, 1998.

46. Matsuda H, Uejima S and Kurita T: Microsatellite instability in renal cell carcinoma and bladder tumors. Hinyokika Kiyo 42: 27-31, 1996.

47. Uchida T, Wada C, Wang C, Egawa S, Ohtani H and Koshiba K: Genomic instability of microsatellite repeats and mutations of $\mathrm{H}-, \mathrm{K}-$, and $\mathrm{N}-\mathrm{ras}$, and $\mathrm{p} 53$ genes in renal cell carcinoma. Cancer Res 54: 3682-3685, 1994.

48. Leach FS, Koh M, Sharma K, et al: Mismatch repair gene mutations in renal cell carcinoma. Cancer Biol Ther 1: 530-536, 2002.

49. Cullinane CA, Ellenhorn JD and Weitzel JN: Microsatellite instability is a rare finding in tumors of patients with both primary renal and rectal neoplasms. Cancer Genet Cytogenet 148: 163-165, 2004. 
50. Poulogiannis G, Frayling IM and Arends MJ: DNA mismatch repair deficiency in sporadic colorectal cancer and Lynch syndrome. Histopathology 56: 167-179, 2010.

51. Seruca R, Velho S, Oliveira C, Leite M, Matos P and Jordan P. Unmasking the role of KRAS and BRAF pathways in MSI colorectal tumors. Expert Rev Gastroenterol Hepatol 3: 5-9, 2009.

52. Oliveira C, Pinto M, Duval A, et al: BRAF mutations characterize colon but not gastric cancer with mismatch repair deficiency. Oncogene 22: 9192-9196, 2003.

53. Jiang W, Kahn SM, Guillem JG, Lu SH and Weinstein IB: Rapid detection of ras oncogenes in human tumors: applications to colon, esophageal, and gastric cancer. Oncogene 4: 923-928, 1989.

54. Lee SH, Lee JW, Soung YH, et al: BRAF and KRAS mutations in stomach cancer. Oncogene 22: 6942-6945, 2003.

55. Lee KH, Lee JS, Suh C et al: Clinicopathologic significance of the K-ras gene codon 12 point mutation in stomach cancer. An analysis of 140 cases. Cancer 75: 2794-2801, 1995.

56. Arber N, Shapira I, Ratan J, et al: Activation of c-K-ras mutations in human gastrointestinal tumors. Gastroenterology 118: 1045-1050, 2000
57. Craanen ME, Blok P, Top B, et al: Absence of ras gene mutations in early gastric carcinomas. Gut 37: 758-762, 1995 .

58. Waldmann V and Rabes HM: Proliferative heterogeneity of human renal cell carcinomas and prevalence of ras gene point mutations. J Cancer Res Clin Oncol 122: 207-213, 1996.

59. Van Krieken JH, Jung A, Kirchner T, et al: KRAS mutation testing for predicting response to anti-EGFR therapy for colorectal carcinoma: proposal for an European quality assurance program. Virchows Arch 453: 417-431, 2008.

60. Brennetot C, Duval A, Hamelin R, Pinto M, Oliveira C, Seruca R and Schwartz S Jr: Frequent Ki-ras mutations in gastric tumors of the MSI phenotype. Gastroenterology 125: 1282, 2003.

61. Pavlovich CP and Schmidt LS: Searching for the hereditary causes of renal-cell carcinoma, Nat Rev Cancer 4: 381-393, 2004.

62. Hansel DE: Genetic alterations and histopathologic findings in familial renal cell carcinoma. Histol Histopathol 21: 437-444, 2006. 